\title{
antibodies
}

ISSN 2073-4468

www.mdpi.com/journal/antibodies

Review

\section{Regulatory B-Cells in Transplantation}

\section{David San Segundo ${ }^{1}$, Marcos López-Hoyos ${ }^{1}{ }^{*}$ and Manuel Arias ${ }^{2}$}

1 Immunology Service, Universitary Hospital Marqués de Valdecilla-IFIMAV, Avd Valdecilla s/n, Santander 39008, Spain; E-Mail: dsansegundo@humv.es

2 Nephrology Service, Universitary Hospital Marqués de Valdecilla-IFIMAV, Avd Valdecilla s/n, Santander 39008, Spain; E-Mail: manarias@humv.es

* Author to whom correspondence should be addressed; E-Mail: inmlhm@humv.es;

Tel.: +34-942-203-453; Fax: +34-942-203-847.

Received: 3 September 2013; in revised form: 22 October 2013 / Accepted: 23 October 2013 / Published: 20 November 2013

\begin{abstract}
B-cells have been long accepted as the main cellular component in humoral responses. Their effector function is based on antibody and cytokine production. The development of donor-specific antibodies by B-cells has deleterious consequences in graft and patients survival. Recently, a new subset of IL-10-secreting B-cells with regulatory capacity in allergic and autoimmune diseases has been shown. Such regulatory function changes the apprehension of B-cells as effector cells and increases the complexity to the immuno-regulatory networks. New therapies targeting B-cells should consider that depleting B-cells potentially impairs regulatory B-cells (Bregs) and that modulating or favoring the maintenance and function of Bregs would be important for the achievement of humoral tolerance. Unfortunately, few direct pieces of evidence of Breg involvement in allograft tolerance models has been described. Here, we summarize the current knowledge of the role of Bregs in transplantation.
\end{abstract}

Keywords: Bregs; IL-10 


\section{Introduction}

\subsection{B-Cell Subsets}

B-cells constitute the main cellular component involved in humoral immune responses. Two different subpopulations of B-cells coexist, B1 and conventional B2 cells. The B1 cells are characterized by cluster differentiation (CD)5 expression and represent less than $5 \%$ of the total B-cell component in peripheral blood in mice, whereas in humans, the CD5 expression in B1 counterpart cells is heterogeneous [1]. B1 cells are present in alveolar and peritoneal cavity and may have a role in mucosal immunity, although IL-10-producing CD5+ B-cells with a regulatory capability have been described [2].

The conventional B2-cells lack CD5 expression and represent the majority of B-cells. The involvement of B-cells in immune responses has long been accepted based on antibody production. However, after several decades of research on various B-cell effector functions, such as cytokine production and professional antigen presentation [3], several B-cells with regulatory capacity were defined. In mice, the innate-like B-cells are composed of marginal zone (MZ) B-cells and other related B-cells and constitute an important source of IL-10-producing regulatory B-cells (Bregs) [4].

\subsection{Mechanisms of Tolerance by B-Cells}

To address the function of regulatory B-cells, the mechanisms used by B-cells to achieve antigen tolerance should be fully understood [5]. The education of lymphocytes for discerning between self and non-self is tightly regulated. It is assumed that the mechanisms of self-tolerance in T-lymphocytes, based in negative and positive selection in the thymus, clonal deletion, clonal anergy, T-cell receptor editing and antigen ignorance, apply also to B-cell precursors [5].

B-cell precursors in the bone marrow differentiate into B-cells with different levels of self-reactivity of their B-cell-receptor (BCR); self-high reactivity BCR, B-cell clones are deleted and only those with less reactivity integrate with the B-cell pool and travel through the peripheral blood to extrafollicular regions. At this point, B-cells can follow two different pathways: T-cell-dependent and -independent.

The T-cell-dependent pathway takes place in follicular regions within peripheral lymphoid tissues and with the help of antigen presenting cells (APCs) and T-helper (Th) cells. In germinal centers, B-cells develop into long-lived plasma cells and memory B-cells that, upon re-challenge with cognate antigen, produce a large amount of antibodies.

In contrast, the T-cell-independent pathway takes place in extra-follicular regions of peripheral lymphoid tissues, and MZ B-cells are able to produce antibodies regardless of Th cells. These B-cells are considered part of the innate immune response and respond vigorously in the early immune response to bloodstream pathogens [6]. In lymphopenic conditions, the transitional B-cells first expand to recover B-cell numbers [7,8]; this observation could have important implications in antibody-depleted transplant recipients. 


\section{B-Cells and Transplantation}

The knowledge of checkpoints in B-cell education allowed for the study of B-cell subsets that are more susceptible to modulation in order to promote alloimmune-humoral tolerance. In a mouse model of a skin-heart transplant, after B-cell reconstitution and rechallenge with alloantibodies, no antibody reaction against the donor was observed [9]. This suggests that the development stage of B-cells in which the encounter with the alloantigen takes place is important for the induction of specific humoral tolerance.

The immune response against the allograft can be divided into cellular and humoral. The latter is characterized mainly by antibody production and complement activation. Both components can result in graft rejection [10]. Within the different B-cell subsets, long-lived plasma cells upon T-cell cooperation and short-lived plasma cells in a T-cell-independent manner are able to produce alloantibodies directed against the donor. This reflects the complexity of the humoral network that is mounted in order to evoke an anti-donor response.

The presence of pre-transplant donor-specific antibodies (DSA), or de-novo post-transplant antibody production, has been shown to correlate with poor survival in all solid organ transplants [11-13] and in hematopoietic stem cell transplantations [14]. In addition, the presence of anti-human leukocyte antigen (HLA) antibodies in the recipient has a deleterious effect, not only in the short term, but also in chronic rejection [11].

Upon any solid organ transplant, life-long immunosuppression is mandatory in order to avoid graft rejection. Nevertheless, several studies report tolerance of liver allografts [15]. Operational tolerance of transplants is defined as complete weaning-off of immunosuppression with maintained graft function [16]. Unfortunately, there is scarce evidence in other solid organ transplants for such a possibility. Recently, a B-cell signature was demonstrated in a small cohort of tolerant kidney transplant recipients (KTR) [17,18]. The Immune Tolerance Network (ITN) and Reprogramming the Immune System for the Establishment of Tolerance (RISET) consortia observed an expansion of B-cells in peripheral blood of these patients, suggesting an expansion of non-effector B-cell subpopulations in tolerant kidney transplant recipients, distinct from alloreactive effector B-cells. The pattern of expansion of naive/transitional B-cells in tolerant KTR suggests an immunoregulatory role of these B-cell subsets. Thus, within the B-cell compartment, different subpopulations exist in the peripheral blood with several maturation stages (Figure 1).

Mature B-lymphocytes are considered not only antibody-secreting cells, but also have a role as professional APCs that interact with T-cells prior to undergoing somatic hypermutation and supplying alloantibodies with higher affinity. These alloantibodies could directly drive an acute humoral rejection [19], but could also enhance alloreactive T-cell activation and evoke an acute cellular rejection [20]. Moreover, memory alloreactive B-cells and alloantibodies are able to break tolerance achieved after an anti-CD154 treatment model [21]. Thus, an overall effector function in allograft response is generally accepted. However, contrasting functions of B-lymphocytes in tolerance models have been demonstrated. In an anti-CD45RB transplant tolerance model, donor-specific tolerance is achieved with the participation of regulatory T-cells (Tregs), where the presence of B-lymphocytes was necessary, suggesting a crosslink between Tregs and B [22]. IL-10 production by both Tregs and Bregs has been proposed as a mechanism of allograft tolerance [23]. 
Figure 1. Potential immunoregulatory network in transplantation: IL-10 and transforming growth factor (TGF)- $\beta$ are the soluble key players in the immunoregulatory network. IL-10 can be secreted after B10 stimulation by Lipopolysaccharide (LPS), CD40 and alloantigenspecific T-cells early in the alloimmune response. IL-10 then evokes a positive loop, activating B10 cells and favoring the maintenance of regulatory T-cells (Tregs), providing an allograft-tolerance environment. TGF- $\beta$ could drive the generation of Treg cells from naive T-cells, but in the presence of IL-6 in the local milieu, TGF- $\beta$ skews the differentiation of naive T-cells to Th17 cells with a potential detrimental role for the allograft. Moreover, TGF- $\beta$ can induce apoptosis in B10 cells, thus blocking the positive loop to tolerance induction. Abbreviations: B10, IL-10 producing-regulatory B-cells; Th, T-helper cells; Tr1, Type 1 regulatory T-cells; Tregs, regulatory T-cells. Arrows: Black, differentiation; striped, production; dotted, positive effect; truncated, negative effect.

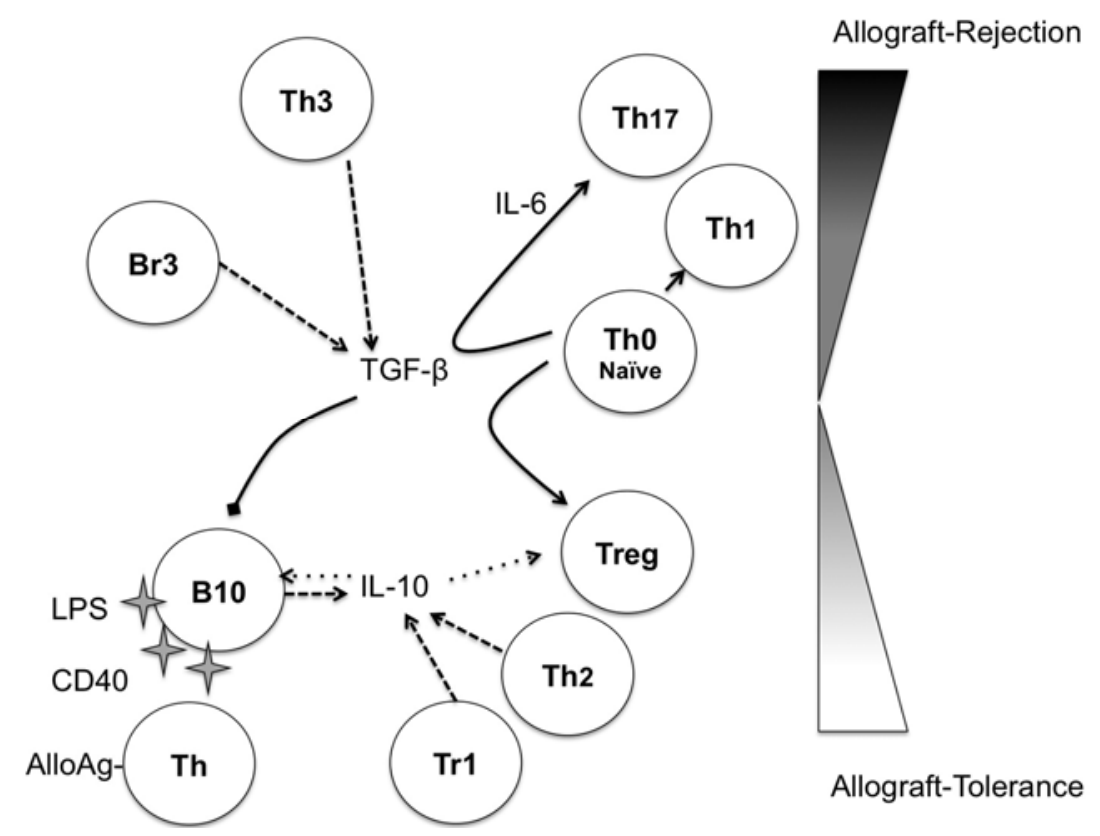

IL-10 has been recognized as a Th2 cytokine that inhibits interferon (IFN)-gamma/Th1 response [24] and has immune-regulatory functions in autoimmunity, allergic diseases and transplant models [25]. The main cell source for IL-10 is the macrophages [26], but it is also produced by Th2 cells [24], type-1 regulatory T-cells (Tr1) [25], monocytes [27], and, recently, by IL-10 producing B (B10)-cells ([2]).

The main function of IL-10 is modulation of APCs and inhibition of naive Th0 cells, as well as IFN-gamma-producing Th1 cells. The inhibitory role on CD8+ T-cells is less clear ([28]).

IL-10 induces Tr1 cells from naive T-cells [29], is important for the maintenance of Tr1 cells [25] and is necessary for the functional activity of CD45RB (low) CD4+ T-cells, responsible for the tolerance to donor alloantigens in vivo [29].

However, some stimulatory functions have been attributed to IL-10 [30,31]. This paradoxical function was confirmed in a heart transplant model, where IL-10 enhanced rejection and the progression of graft arterial disease [32]. In the anti-CD45RB transplant tolerance model, IL-10 exacerbated graft rejection [33]. 
Overcoming the latter findings, the vast majority of the published data on IL-10 define it as an immunoregulatory cytokine. Thus, IL-10 produced by Bregs can facilitate Treg function and induce allograft-tolerance.

\section{Regulatory B-Cells}

Several subpopulations of B-cells with regulatory functions have been assigned as Bregs, including IL-10-producing Bregs (B10 or Br1); TGF- $\beta$-producing B-cells (Br3) and Foxp3+ B-cells. Their characteristics in mice and humans are summarized in Table 1.

Table 1. Comparison between different regulatory B-cell (Breg) subsets and mechanism of regulation.

\begin{tabular}{|c|c|c|c|c|}
\hline Subject & & Phenotype & $\begin{array}{l}\text { Suppressive } \\
\text { mediator }\end{array}$ & Refs. \\
\hline \multirow{5}{*}{ Mice } & B1-like & $\mathrm{CD}^{+}$ & FasL & {$[34]$} \\
\hline & $\mathrm{B} 10$ & $\mathrm{CD}^{+} \mathrm{CD} 1 \mathrm{~d}^{\text {high }}$ & IL-10 & [35] \\
\hline & $\mathrm{B} 10$ & $\mathrm{CD} 21^{\text {high }} \mathrm{CD} 23^{\text {high }} \mathrm{CD} 1 \mathrm{~d}^{\text {high }}$ & IL-10 & [36] \\
\hline & $\mathrm{B} 10$ & $\begin{array}{l}\text { T cell Ig domain and mucin } \\
\text { domain protein }(\mathrm{TIM})^{+}\end{array}$ & IL-10 & {$[37]$} \\
\hline & $\mathrm{Br} 3$ & Unknown & TGF- $\beta$ & [38] \\
\hline \multirow{4}{*}{ Humans } & Br1 & $\mathrm{CD} 24^{\text {high }} \mathrm{CD} 38^{\text {high }}$ & IL-10 & [39] \\
\hline & Br1 & $\mathrm{CD} 24^{\text {high }} \mathrm{CD} 27^{+}$ & IL-10 & {$[40]$} \\
\hline & $\mathrm{Br} 3$ & Unknown & TGF- $\beta$ & {$[41]$} \\
\hline & Foxp3+ & $\mathrm{CD}_{19}{ }^{\text {low }} \mathrm{Foxp}^{+}$ & Unknown & [42] \\
\hline
\end{tabular}

The first B-cell subpopulation described as having regulatory properties was defined as CD1d ${ }^{\text {high }}$ [43]. Although the regulatory mechanisms of Bregs are not fully elucidated, the production of IL-10 has been well characterized [2]. The $\mathrm{CD} 19+\mathrm{CD} 5+\mathrm{CD} 1 \mathrm{~d}^{\text {high }} \mathrm{B}$-cells $(\mathrm{B} 10)$ are responsible for the main production of IL-10 [2] and, upon activation with LPS or anti-CD40, undergo B10 maturation [35]. The activation of Bregs may control inflammatory responses in both a T-cell-dependent and an antigen-specific manner [44]. Indeed, the timing of B-cell depletion was found to have paradoxical results in experimental autoimmune encephalomyelitis (EAE) after myelin oligodendrocyte glycoprotein immunization: B-cell depletion before immunization enhances specific T-cell responses, suggesting a regulatory role for B-cells, whereas B-cell depletion two weeks after immunization diminishes specific T-cell response [44].

Importantly, IL-10 enhances the proliferation of CD5+ B-cells with regulatory properties in an autocrine manner [45]. IL-10 produced by B10 cells can induce Tr1 cells [29], thus further enhancing the regulation of alloimmune-responses (Figure 1).

Another subset of B-cells was subsequently identified, B-cells secreting TGF- $\beta$ [38]. The nomenclature for this subset, with analogy to TGF- $\beta$-secreting T-cells ( Tr3), was $\mathrm{Br} 3$. The $\mathrm{Br} 3$ cells are heterogeneous in CD5 expression and were studied in models of allergic diseases [46] and in humans [41]. In contrast to IL-10, TGF- $\beta$ promotes apoptosis of CD5+ B-cells [47] and could act as a negative regulator of B10 cells. TGF- $\beta$ alone could drive naive T-cells into inducible Tregs (iTreg) $[48,49]$, enhancing the regulatory environment, but together with IL-6, TGF- $\beta$ could skew naive T-cells toward 
IL-17-secreting (Th17) cells and tip the balance towards effector T-cells [50]. It seems that the local cytokine environment is crucial to define the role of TGF- $\beta$ in allograft tolerance (Figure 1).

Finally, a fork-head box 33 (Foxp3) transcription factor and master gene of natural Tregs was found to be expressed in a B-cell subpopulation [42], but its suppressor capacity remains to be demonstrated.

In humans, several B-cell subsets with regulatory properties have been described in healthy subjects [39]. The human Breg population is CD19+ with high expression of CD24 and CD38 [39], similar to the immature and early stages of transitional B-cells (Figure 2). Impairment in the regulatory capacity of $\mathrm{CD} 19+\mathrm{CD} 24^{\text {high }} \mathrm{CD} 38^{\text {high }}$ cells in rheumatoid arthritis [39] and a decrease in IL-10-producing, CD24 ${ }^{\text {high }} \mathrm{CD} 27^{+}$B-cells in Graves' disease [40] have been described.

Figure 2. B-cells ontogeny, markers of B-cell subpopulations and monoclonal antibody treatment susceptibility. (Top) Origin and development pathways of B-cell subsets and localization in the peripheral tissues. (Middle) Different markers of B-cell subsets regarding maturational stage: background red (high expression); orange (medium expression), green (low expression); blue (no expression); line crossed (not defined). (Bottom) Antibody treatments targeting the B-cell compartment; susceptible subpopulation (black arrow); intermediate susceptibility (striped arrow). Abbreviations: T, transitional; MZ, marginal zone; MEM, memory; BLyS, B-lymphocyte-stimulator; BAFF, B-cell-activating factor.

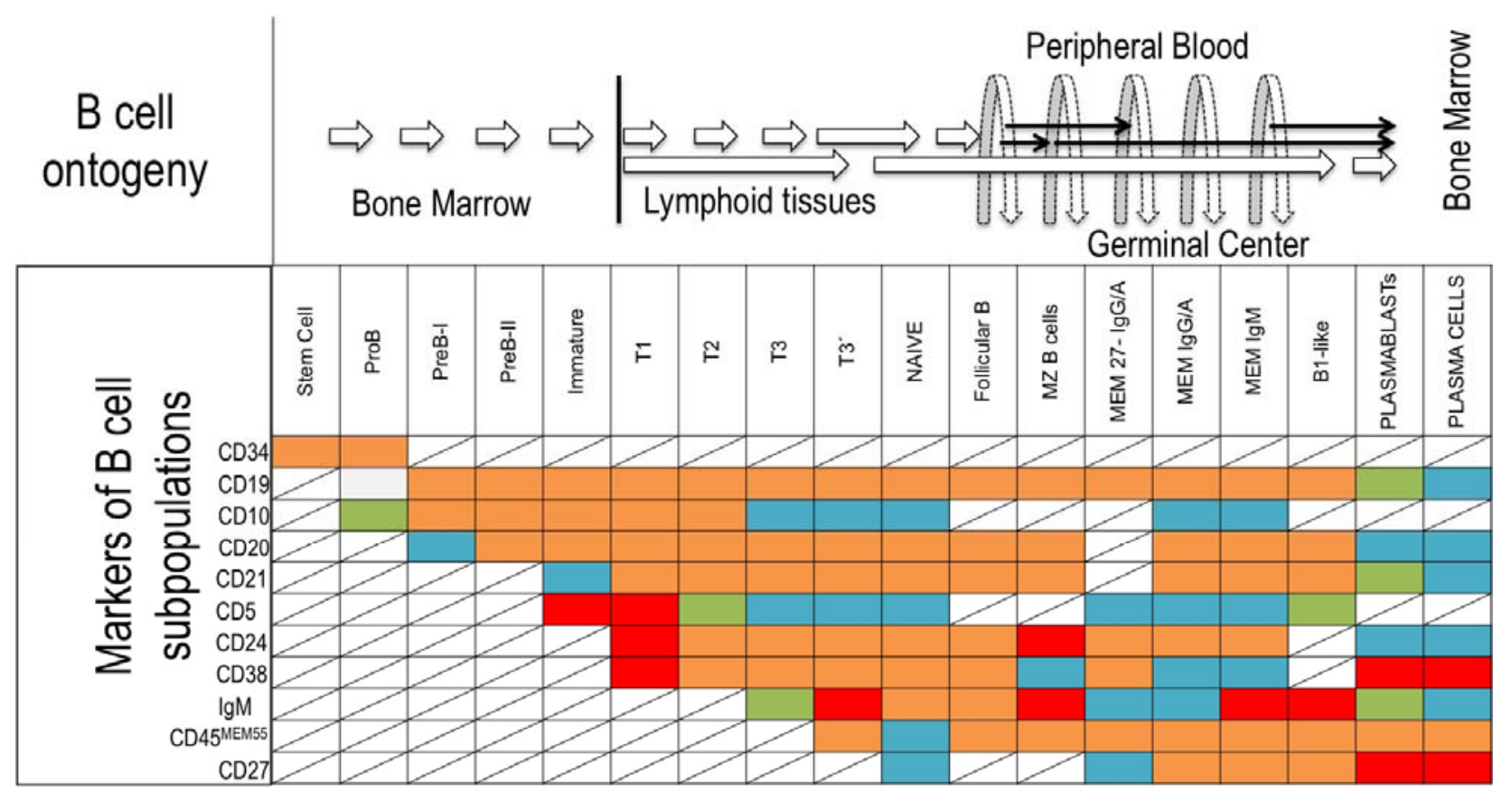

Rituximab (anti-CD20)

Anti-BLyS

Atacicept (anti-BLyS and anti-BAFF)

Alemtuzumab (anti-CD52)

Bortezomib 


\section{Bregs and Clinical Transplantation}

The direct involvement of Bregs in clinical transplantation has not been fully studied. Depleting B-cells with monoclonal antibodies in the presence of alloantigen to promote donor-specific humoral tolerance has been suggested $[9,51]$. There are few studies with a limited number of KTR patients. In a cohort of KTR treated with Alemtuzumab (Campath-1H) and anti-CD52 monoclonal antibody that depletes B- and T-cell populations during two to six, even 12, months post-induction, a transient increase of immature and transitional B-cell subpopulations was found [52], suggesting that Campath-1H-treated KTR could modulate several populations with regulatory functions and achieve the B-cell signature observed in tolerant KTR [17,18]. This observation could, however, be skewed, due to homeostatic proliferation of transitional and naive B-cells in lymphopenic hosts after treatment with Rituximab [7]. Recently, a higher incidence of DSA development was demonstrated in a prospective study after Alemtuzumab induction and, consequently, impaired graft function compared with basiliximab and anti-thymoglobulin treated groups [53].

It has been hypothesized that target subpopulations involved in checkpoints of antigen-tolerance would be a feasible strategy to achieve B tolerance, combining antibodies against survival factors of B-cells, such as B-lymphocyte-stimulator (BlyS) and B-cell-activating factor (BAFF), with anti-CD20 therapy. The immature expanding B-cells would come in contact with an alloantigen and would be recognized as self-antigen, achieving humoral tolerance to the allograft [54].

\section{Conclusion}

The role of Bregs in allograft tolerance remains largely to be studied. To date, the best documented regulatory function is based on IL-10. Other mechanistic functions are probably waiting to be elucidated.

\section{Acknowledgments}

This work was partially funded by Fundación Marqués de Valdecilla-IFIMAV (API 11/24); Fondo de Investigaciones Sanitarias (PI08-0157, PI11-00990 and RENDIREN 06/16) grants.

\section{Conflicts of Interest}

The authors declare no conflict of interest.

\section{References}

1. Griffin, D.O.; Rothstein, T.L. A small cd11b(+) human b1 cell subpopulation stimulates $\mathrm{t}$ cells and is expanded in lupus. J. Exp. Med. 2011, 208, 2591-2598.

2. Yanaba, K.; Bouaziz, J.D.; Matsushita, T.; Tsubata, T.; Tedder, T.F. The development and function of regulatory b cells expressing il-10 (b10 cells) requires antigen receptor diversity and tlr signals. J. Immunol. 2009, 182, 7459-7472. 
3. Wennhold, K.; Shimabukuro-Vornhagen, A.; Theurich, S.; von Bergwelt-Baildon, M. Cd40-activated b cells as antigen-presenting cells: The final sprint toward clinical application. Expert Rev. Vaccines 2013, 12, 631-637.

4. Zhang, X. Regulatory functions of innate-like b cells. Cell. Mol. Immunol. 2013, 10, 113-121.

5. Goodnow, C.C.; Sprent, J.; Fazekas de St Groth, B.; Vinuesa, C.G. Cellular and genetic mechanisms of self tolerance and autoimmunity. Nature 2005, 435, 590-597.

6. Lopes-Carvalho, T.; Kearney, J.F. Development and selection of marginal zone b cells. Immunol. Rev. 2004, 197, 192-205.

7. Palanichamy, A.; Barnard, J.; Zheng, B.; Owen, T.; Quach, T.; Wei, C.; Looney, R.J.; Sanz, I.; Anolik, J.H. Novel human transitional b cell populations revealed by $\mathrm{b}$ cell depletion therapy. J. Immunol. 2009, 182, 5982-5993.

8. Meyer-Bahlburg, A.; Andrews, S.F.; Yu, K.O.; Porcelli, S.A.; Rawlings, D.J. Characterization of a late transitional $\mathrm{b}$ cell population highly sensitive to baff-mediated homeostatic proliferation. J. Exp. Med. 2008, 205, 155-168.

9. Parsons, R.F.; Vivek, K.; Rostami, S.Y.; Zekavat, G.; Ziaie, S.M.; Luo, Y.; Koeberlein, B.; Redfield, R.R.; Cancro, M.P.; Naji, A.; et al. Acquisition of humoral transplantation tolerance upon de novo emergence of b lymphocytes. J. Immunol. 2011, 186, 614-620.

10. Cai, J.; Terasaki, P.I. Humoral theory of transplantation: Mechanism, prevention, and treatment. Hum. Immunol. 2005, 66, 334-342.

11. Fidler, S.J.; Irish, A.B.; Lim, W.; Ferrari, P.; Witt, C.S.; Christiansen, F.T. Pre-transplant donor specific anti-hla antibody is associated with antibody-mediated rejection, progressive graft dysfunction and patient death. Transpl. Immunol. 2013, 28, 148-153.

12. Lobo, L.J.; Aris, R.M.; Schmitz, J.; Neuringer, I.P. Donor-specific antibodies are associated with antibody-mediated rejection, acute cellular rejection, bronchiolitis obliterans syndrome, and cystic fibrosis after lung transplantation. J. Heart Lung Transplant. 2013, 32, 70-77.

13. Kaczmarek, I.; Deutsch, M.A.; Kauke, T.; Beiras-Fernandez, A.; Schmoeckel, M.; Vicol, C.; Sodian, R.; Reichart, B.; Spannagl, M.; Ueberfuhr, P. Donor-specific hla alloantibodies: Long-term impact on cardiac allograft vasculopathy and mortality after heart transplant. Exp. Clin. Transplant. 2008, 6, 229-235.

14. Detrait, M.; Dubois, V.; Sobh, M.; Morisset, S.; Tedone, N.; Labussiere, H.; Gillis, L.; Barraco, F.; Cannas, G.; Ducastelle, S.; et al. Impact of anti-hla antibodies on allogeneic hematopoietic stem cell transplantation outcomes after reduced-intensity conditioning regimens. Exp. Hematol. 2012, 40, 792-799.

15. Martinez-Llordella, M.; Puig-Pey, I.; Orlando, G.; Ramoni, M.; Tisone, G.; Rimola, A.; Lerut, J.; Latinne, D.; Margarit, C.; Bilbao, I.; et al. Multiparameter immune profiling of operational tolerance in liver transplantation. Am. J. Transplant. 2007, 7, 309-319.

16. Tryphonopoulos, P.; Ruiz, P.; Weppler, D.; Nishida, S.; Levi, D.M.; Moon, J.; Tekin, A.; Velez, M.; Neuman, D.R.; Island, E.; et al. Long-term follow-up of 23 operational tolerant liver transplant recipients. Transplantation 2010, 90, 1556-1561.

17. Sagoo, P.; Perucha, E.; Sawitzki, B.; Tomiuk, S.; Stephens, D.A.; Miqueu, P.; Chapman, S.; Craciun, L.; Sergeant, R.; Brouard, S.; et al. Development of a cross-platform biomarker signature to detect renal transplant tolerance in humans. J. Clin. Invest. 2010, 120, 1848-1861. 
18. Newell, K.A.; Asare, A.; Kirk, A.D.; Gisler, T.D.; Bourcier, K.; Suthanthiran, M.; Burlingham, W.J.; Marks, W.H.; Sanz, I.; Lechler, R.I.; et al. Identification of a b cell signature associated with renal transplant tolerance in humans. J. Clin. Invest. 2010, 120, 1836-1847.

19. Patel, R.; Terasaki, P.I. Significance of the positive crossmatch test in kidney transplantation. N. Engl. J. Med. 1969, 280, 735-739.

20. Burns, A.M.; Chong, A.S. Alloantibodies prevent the induction of transplantation tolerance by enhancing alloreactive t cell priming. J. Immunol. 2011, 186, 214-221.

21. Burns, A.M.; Ma, L.; Li, Y.; Yin, D.; Shen, J.; Xu, J.; Chong, A.S. Memory alloreactive b cells and alloantibodies prevent anti-cd154-mediated allograft acceptance. J. Immunol. 2009, 182, 1314-1324.

22. Deng, S.; Moore, D.J.; Huang, X.; Lian, M.M.; Mohiuddin, M.; Velededeoglu, E.; Lee, M.K.t.; Sonawane, S.; Kim, J.; Wang, J.; et al. Cutting edge: Transplant tolerance induced by anti-cd45rb requires b lymphocytes. J. Immunol. 2007, 178, 6028-6032.

23. Battaglia, M.; Roncarolo, M.G. The role of cytokines (and not only) in inducing and expanding $\mathrm{t}$ regulatory type 1 cells. Transplantation 2004, 77, S16-S18.

24. Fiorentino, D.F.; Bond, M.W.; Mosmann, T.R. Two types of mouse t helper cell. Iv. Th2 clones secrete a factor that inhibits cytokine production by th1 clones. J. Exp. Med. 1989, 170, 2081-2095.

25. Gregori, S.; Goudy, K.S.; Roncarolo, M.G. The cellular and molecular mechanisms of immunosuppression by human type 1 regulatory t cells. Front. Immunol. 2012, 3, 30.

26. Spits, H.; de Waal Malefyt, R. Functional characterization of human il-10. Int Arch. Allergy Immunol. 1992, 99, 8-15.

27. de Waal Malefyt, R.; Abrams, J.; Bennett, B.; Figdor, C.G.; de Vries, J.E. Interleukin 10(il-10) inhibits cytokine synthesis by human monocytes: An autoregulatory role of il-10 produced by monocytes. J. Exp. Med. 1991, 174, 1209-1220.

28. Brooks, D.G.; Walsh, K.B.; Elsaesser, H.; Oldstone, M.B. Il-10 directly suppresses cd4 but not cd $8 \mathrm{t}$ cell effector and memory responses following acute viral infection. Proc. Natl. Acad. Sci. USA 2010, 107, 3018-3023.

29. Levings, M.K.; Sangregorio, R.; Galbiati, F.; Squadrone, S.; de Waal Malefyt, R.; Roncarolo, M.G. Ifn-alpha and il-10 induce the differentiation of human type $1 \mathrm{t}$ regulatory cells. J. Immunol. 2001, 166, 5530-5539.

30. Tilg, H.; van Montfrans, C.; van den Ende, A.; Kaser, A.; van Deventer, S.J.; Schreiber, S.; Gregor, M.; Ludwiczek, O.; Rutgeerts, P.; Gasche, C.; et al. Treatment of crohn's disease with recombinant human interleukin 10 induces the proinflammatory cytokine interferon gamma. Gut 2002, 50, 191-195.

31. Lauw, F.N.; Pajkrt, D.; Hack, C.E.; Kurimoto, M.; van Deventer, S.J.; van der Poll, T. Proinflammatory effects of il-10 during human endotoxemia. J. Immunol. 2000, 165, 2783-2789.

32. Furukawa, Y.; Becker, G.; Stinn, J.L.; Shimizu, K.; Libby, P.; Mitchell, R.N. Interleukin-10 (il-10) augments allograft arterial disease: Paradoxical effects of il-10 in vivo. Am. J. Pathol. 1999, 155, 1929-1939.

33. Zhao, G.; Moore, D.J.; Lee, K.M.; Kim, J.I.; Duff, P.E.; O’Connor, M.R.; Hirohashi, T.; Lei, J.; Yang, M.; Markmann, J.F.; et al. An unexpected counter-regulatory role of il-10 in b-lymphocytemediated transplantation tolerance. Am. J. Transplant. 2010, 10, 796-801. 
34. Tanner, J.E.; Alfieri, C. Epstein-barr virus induces fas (cd95) in t cells and fas ligand in b cells leading to t-cell apoptosis. Blood 1999, 94, 3439-3447.

35. Yanaba, K.; Bouaziz, J.D.; Haas, K.M.; Poe, J.C.; Fujimoto, M.; Tedder, T.F. A regulatory b cell subset with a unique cd1dhicd5+ phenotype controls t cell-dependent inflammatory responses. Immunity 2008, 28, 639-650.

36. Yang, M.; Sun, L.; Wang, S.; Ko, K.H.; Xu, H.; Zheng, B.J.; Cao, X.; Lu, L. Novel function of b cell-activating factor in the induction of il-10-producing regulatory b cells. J. Immunol. 2010, 184, 3321-3325.

37. Ding, Q.; Yeung, M.; Camirand, G.; Zeng, Q.; Akiba, H.; Yagita, H.; Chalasani, G.; Sayegh, M.H.; Najafian, N.; Rothstein, D.M. Regulatory b cells are identified by expression of tim-1 and can be induced through tim-1 ligation to promote tolerance in mice. J. Clin. Invest. 2011, 121, 3645-3656.

38. Lotz, M.; Ranheim, E.; Kipps, T.J. Transforming growth factor beta as endogenous growth inhibitor of chronic lymphocytic leukemia b cells. J. Exp. Med. 1994, 179, 999-1004.

39. Blair, P.A.; Norena, L.Y.; Flores-Borja, F.; Rawlings, D.J.; Isenberg, D.A.; Ehrenstein, M.R.; Mauri, C. Cd19(+)cd24(hi)cd38(hi) b cells exhibit regulatory capacity in healthy individuals but are functionally impaired in systemic lupus erythematosus patients. Immunity 2010, 32, 129-140.

40. Zha, B.; Wang, L.; Liu, X.; Liu, J.; Chen, Z.; Xu, J.; Sheng, L.; Li, Y.; Chu, Y. Decrease in proportion of $\mathrm{cd} 19+\mathrm{cd} 24(\mathrm{hi}) \mathrm{cd} 27+\mathrm{b}$ cells and impairment of their suppressive function in graves' disease. PLoS One 2012, 7, e49835.

41. Lee, J.H.; Noh, J.; Noh, G.; Choi, W.S.; Cho, S.; Lee, S.S. Allergen-specific transforming growth factor-beta-producing cd19+cd5+ regulatory b-cell (br3) responses in human late eczematous allergic reactions to cow's milk. J. Interferon Cytokine Res. 2011, 31, 441-449.

42. Noh, J.; Choi, W.S.; Noh, G.; Lee, J.H. Presence of foxp3-expressing cd19(+)cd5(+) b cells in human peripheral blood mononuclear cells: Human $\operatorname{cd} 19(+) \operatorname{cd} 5(+)$ foxp3(+) regulatory b cell (breg). Immune Netw. 2010, 10, 247-249.

43. Mizoguchi, A.; Mizoguchi, E.; Takedatsu, H.; Blumberg, R.S.; Bhan, A.K. Chronic intestinal inflammatory condition generates il-10-producing regulatory $\mathrm{b}$ cell subset characterized by cd1d upregulation. Immunity 2002, 16, 219-230.

44. Matsushita, T.; Yanaba, K.; Bouaziz, J.D.; Fujimoto, M.; Tedder, T.F. Regulatory b cells inhibit eae initiation in mice while other b cells promote disease progression. J. Clin. Invest. 2008, 118, 3420-3430.

45. Kitabayashi, A.; Hirokawa, M.; Miura, A.B. The role of interleukin-10 (il-10) in chronic b-lymphocytic leukemia: Il-10 prevents leukemic cells from apoptotic cell death. Int. J. Hematol. 1995, 62, 99-106.

46. Natarajan, P.; Singh, A.; McNamara, J.T.; Secor, E.R., Jr.; Guernsey, L.A.; Thrall, R.S.; Schramm, C.M. Regulatory b cells from hilar lymph nodes of tolerant mice in a murine model of allergic airway disease are cd5+, express tgf-beta, and co-localize with cd4+foxp3+ $\mathrm{t}$ cells. Mucosal Immunol. 2012, 5, 691-701.

47. Vitale, G.; Mion, F.; Pucillo, C. Regulatory b cells: Evidence, developmental origin and population diversity. Mol. Immunol. 2010, 48, 1-8. 
48. Chen, W.; Jin, W.; Hardegen, N.; Lei, K.J.; Li, L.; Marinos, N.; McGrady, G.; Wahl, S.M. Conversion of peripheral $c d 4+\mathrm{cd} 25$ - naive $\mathrm{t}$ cells to $\mathrm{cd} 4+\mathrm{cd} 25+$ regulatory $\mathrm{t}$ cells by tgf-beta induction of transcription factor foxp3. J. Exp. Med. 2003, 198, 1875-1886.

49. Marie, J.C.; Letterio, J.J.; Gavin, M.; Rudensky, A.Y. Tgf-beta1 maintains suppressor function and foxp3 expression in cd4+cd25+ regulatory t cells. J. Exp. Med. 2005, 201, 1061-1067.

50. Zheng, S.G. Regulatory t cells vs th17: Differentiation of th17 versus treg, are the mutually exclusive? Am. J. Clin. Exp. Immunol. 2013, 2, 94-106.

51. Parsons, R.F.; Vivek, K.; Redfield, R.R., 3rd; Migone, T.S.; Cancro, M.P.; Naji, A.; Noorchashm, H. B-lymphocyte homeostasis and blys-directed immunotherapy in transplantation. Transplant. Rev. (Orlando) 2010, 24, 207-221.

52. Heidt, S.; Hester, J.; Shankar, S.; Friend, P.J.; Wood, K.J. B cell repopulation after alemtuzumab induction-transient increase in transitional $\mathrm{b}$ cells and long-term dominance of naive $\mathrm{b}$ cells. Am. J. Transplant. 2012, 12, 1784-1792.

53. Todeschini, M.; Cortinovis, M.; Perico, N.; Poli, F.; Innocente, A.; Cavinato, R.A.; Gotti, E.; Ruggenenti, P.; Gaspari, F.; Noris, M.; et al. In kidney transplant patients, alemtuzumab but not basiliximab/low-dose rabbit anti-thymocyte globulin induces b cell depletion and regeneration, which associates with a high incidence of de novo donor-specific anti-hla antibody development. J. Immunol. 2013, 191, 2818-2828.

54. Parsons, R.F.; Vivek, K.; Redfield, R.R.; Migone, T.S.; Cancro, M.P.; Naji, A.; Noorchashm, H. B-cell tolerance in transplantation: Is repertoire remodeling the answer? Expert Rev. Clin. Immunol. 2009, 5, 703-723.

(C) 2013 by the authors; licensee MDPI, Basel, Switzerland. This article is an open access article distributed under the terms and conditions of the Creative Commons Attribution license (http://creativecommons.org/licenses/by/3.0/). 